Web Jurnal:

http://ejournal.kemenperin.go.id/jli

\title{
Pengaruh hidrolisis menggunakan asam sulfat pada karakteristik micro- fibrillated cellulose (MFC) dari serat tandan kosong kelapa sawit (TKKS) sebagai agen nukleasi
}

\section{The effect of hydrolysis using sulphuric acid on the characteristics of micro- fibrillated cellulose (MFC) based on oil palm empty fruit bunch (OPEFB) fiber as a nucleating agent} \author{
dan Bumiarto Nugroho Jati \\ Badan Penelitian dan Pengembangan Industri, Kementerian Perindustrian \\ Jalan Jenderal Gatot Subroto Kav. 52-53, Jakarta Selatan, Indonesia \\ * agustinaarianita@gmail.com
}

Agustina Arianita Cahyaningtyas*, Bunda Amalia, Evana Yuanita, Rizka Karima, Tiara Mailisa,

\begin{tabular}{l}
\hline INFO ARTIKEL \\
\hline Sejarah artikel: \\
Diterima: \\
17 Februari 2020 \\
Direvisi: \\
4 Juni 2020 \\
Diterbitkan: \\
29 Juni 2020
\end{tabular}

\section{Kata kunci:}

serat tandan kosong kelapa sawit (TKKS); micro-fibrillated cellulose (MFC); agen nukleasi; hidrolisis asam

\section{Keywords:}

palm oil empty fruit bunch fiber (OPEFB); micro-fibrillated cellulose (MFC); nucleating agents; acid hydrolysis

\begin{abstract}
ABSTRAK
Micro-fibrillated cellulose (MFC) dapat diproduksi dari ekstraksi serat Tandan Kosong Kelapa Sawit (TKKS) melalui proses alkalinisasi, oksidasi $\mathrm{H}_{2} \mathrm{O}_{2}$, dan hidrolisis asam. Tujuan dari penelitian ini adalah untuk mengetahui pengaruh waktu reaksi terhadap proses hidrolisis $\mathrm{H}_{2} \mathrm{SO}_{4}$. $M F C$ dibuat dengan proses alkalinisasi menggunakan natrium hidroksida $(\mathrm{NaOH}) 4 \%$ pada suhu $90{ }^{\circ} \mathrm{C}$ selama 2 jam, oksidasi $\mathrm{H}_{2} \mathrm{O}_{2} 20 \%$ pada suhu kamar selama 2 jam, dan hidrolisis $\mathrm{H}_{2} \mathrm{SO}_{4}$ pada suhu kamar. Hidrolisis asam dilakukan menggunakan $\mathrm{H}_{2} \mathrm{SO}_{4} 20 \%$ dengan variasi waktu reaksi 1 jam, 2 jam, dan 3 jam. $M F C$ dianalisis menggunakan Fourier Transform Infrared Spectroscopy (FTIR), X-Ray Difraction (XRD), dan Thermal Gravimetric Analysis (TGA). Analisis FTIR menunjukkan bahwa terjadi penurunan konsentrasi lignin dan selulosa, analisis $T G A$ menunjukkan stabilitas termal pada waktu reaksi 3 jam lebih tinggi dibandingkan waktu reaksi lainnya, dan analisis $X R D$ menunjukkan bahwa semakin lama waktu hidrolisis $\mathrm{H}_{2} \mathrm{SO}_{4}$ terjadi kecenderungan persentase kristalisasi meningkat. Dari hasil yang diperoleh, $M F C$ dari serat TKKS memiliki potensi untuk digunakan sebagai agen nukleasi dalam polimer.
\end{abstract}

\begin{abstract}
Micro-fibrillated cellulose (MFC) can be produced from Oil Palm Empty Fruit Bunch $(\mathrm{OPEFB})$ fiber extraction through the process of alkalinization, $\mathrm{H}_{2} \mathrm{O}_{2}$ oxidation, and acid hydrolysis. The purpose of this study was to determine the effect of reaction time on the $\mathrm{H}_{2} \mathrm{SO}_{4}$ hydrolysis process. MFC prepared by an alkalinization process with $4 \%$ sodium hydroxide (NaOH) at $90{ }^{\circ} \mathrm{C}$ for 2 hours, oxidation of $20 \% \mathrm{H}_{2} \mathrm{O}_{2}$ at room temperature for 2 hours, and hydrolysis with $\mathrm{H}_{2} \mathrm{SO}_{4}$ at room temperature. Acid hydrolysis was carried out using 20\% $\mathrm{H}_{2} \mathrm{SO}_{4}$ with variations in reaction time of 1 hour, 2 hours, and 3 hours. The MFC were analyzed using Fourier Transform Infrared Spectroscopy (FTIR), X-Ray Diffraction (XRD), and Thermal Gravimetric Analysis (TGA). FTIR analysis showed that there was a decrease in lignin and cellulose concentrations, TGA analysis showed thermal stability at the reaction time 3 hours higher than other reaction times, and XRD analysis showed that the longer the hydrolysis time of $\mathrm{H}_{2} \mathrm{SO}_{4}$ there was a tendency for the percentage of crystallization to increase. From the results obtained, MFC from OPEFB had a potential to be used as nucleation agents in polymers.
\end{abstract}




\section{Pendahuluan}

TKKS dari hasil pengolahan minyak kelapa sawit merupakan salah satu biomasa yang sangat berlimpah dan belum dimanfaatkan secara optimal. TKKS dimanfaatkan untuk bahan bakar boiler, kompos, dan sisanya menjadi limbah. Komponen penyusun TKKS antara lain selulosa, lignin, holoselulosa, hemiselulosa, air, dan ekstraktif lain. Selulosa yang terkandung dalam TKSS sebesar 38,76\% atau sekitar 37,50\% dengan kandungan serat mencapai $72,67 \%$. Oleh karena itu TKKS potensial untuk menjadi raw material yang diambil selulosanya (Dewanti, 2018).

Selulosa merupakan substansi yang tidak larut di dalam air, terdapat di dalam dinding sel tumbuhan terutama pada bagian batang, tangkai, dan semua bagian yang mengandung kayu. Selulosa merupakan homopolisakarida yang mempunyai molekul berbentuk linear. Struktur linear ini menyebabkan selulosa bersifat kristalin dan tidak mudah larut. Selulosa tidak mudah terdegradasi secara kimia maupun mekanis. Di alam, biasanya selulosa berasosiasi dengan polisakarida lain seperti hemiselulosa atau lignin membentuk rangka utama dinding sel tumbuhan (Pradana et al., 2017). MFC (microcrystalline cellulose) merupakan derivat selulosa. Energi yang dibutuhkan untuk memproduksi $M F C$ lebih sedikit dibandingkan derivat selulosa yang lain. Ekstraksi $M F C$ dari serat TKKS dapat meningkatkan nilai tambah serat TKKS. MFC memiliki struktur fibrillar dan ikatan hidrogen dalam jumlah besar yang membentuk struktur kristal tiga dimensi, sehingga $M F C$ memiliki banyak wilayah kristal. Wilayah kristal ini terkait dengan sifat fisik $M F C$ (Yuanita et al., 2015).

Nucleating agents pada proses nukleasi bertindak sebagai seed dan meningkatkan kecepatan kristalisasi. Nucleating agents juga dapat meningkatkan kinetika kristalisasi dan mengurangi waktu siklus injection molding, sehingga dapat mengurangi biaya produksi polimer. Efisiensi nucleating agents berdasarkan pada ukuran partikel, morfologi, struktur kimia, dan perilaku ketika digabungkan dengan polimer (Simanke et al., 2016).

Penelitian-penelitian yang telah dilakukan dan menunjukkan bahwa serat alam dapat dijadikan nucleating agents antara lain preparasi $M F C$ dari serat Arenga Pinnata "Ijuk" untuk nucleating agent pada polipropilena, $M F C$ sebagai nucleating agent pada foam polivinil alkohol, MFC sebagai nucleating agent untuk polipropilena, dan nanofibrillated cellulose (NFC) sebagai nucleating agent untuk polivinil alkohol (Gentile et al., 2018; Thanomchat et al., 2014; Yuanita et al., 2017; Yuwawech et al., 2015). MFC memiliki karakteristik berupa fibril, memiliki banyak ikatan hidrogen yang membentuk struktur kristal tigadimensi, dan memiliki keunggulan atas kristalinitasnya (Mustafa et al., 2015). Oleh karena itu, MFC dari serat TKKS berpotensi sebagai nucleating agent untuk meningkatkan kecepatan kristalisasi.

Komposisi struktur serat alam yang terdiri dari selulosa, hemiselulosa, dan lignin menyebabkan terjadinya penyerapan kelembaban dari lingkungan, sehingga kompatibilitas serat dengan matriks material non polar rendah (Kabir et al., 2012). Oleh karena itu diperlukan perlakuan tertentu pada permukaan serat untuk meningkatkan kompatibilitas $M F C$ dengan matrik. Beberapa metode untuk meningkatkan kompatibilas $M F C$ antara lain dengan asetilasi (Lepetit et al., 2017), proses alkalinisasi dilanjutkan dengan asetilasi dengan penambahan $\mathrm{H}_{2} \mathrm{SO}_{4}$ (Ismojo et al., 2017), metode multistages (alkalinisasi, oksidasi, dan hidrolisis asam sulfat) (Yuanita et al., 2015), hidrolisis asam sulfat parsial (Saputro et al., 2017), alkalinisasi dilanjutkan dengan bleaching (Ismojo et al., 2019), dan Fenton pretreatment (Hellström et al., 2014). Alkalinisasi adalah proses untuk melarutkan lignin dan pengotor yang terdapat pada permukaan serat, oksidasi adalah proses penghilangan lapisan pengikat antara selulosa untuk membentuk mikrofibril, sedangkan hidrolisis asam digunakan untuk mendegradasi selulosa amorph dan menurunkan konsentrasi -OH (Ching and Ng, 2014; Lismeri and Darni, 2017; Mustafa et al., 2015; Nasution et al., 2017; Pradana et al., 2017; Tristantini et al., 2017).

Asam sulfat $\left(\mathrm{H}_{2} \mathrm{SO}_{4}\right)$ dan asam klorida umumnya digunakan pada proses hidrolisis asam untuk menghilangkan bagian amorph selulosa. Kondisi proses seperti rasio asam-serat, waktu reaksi, suhu, konsentrasi asam, dan tipe asam mempengaruhi hasil hidrolisis asam. Asam sulfat mengakibatkan suspensi yang sangat stabil dengan masuknya permukaan aktif gugus kristalit sulfat (Khalil et al., 2011; Wulandari et al., 2016a). Salah satu faktor penting pada proses hidrolisis selulosa menggunakan asam adalah waktu reaksi (Al-Dulaimi and Wanrosli, 2017).

Saat ini banyak penelitian yang berfokus pada hidrolisis selulosa menggunakan asam, antara lain hidrolisis asam menggunakan $\mathrm{H}_{2} \mathrm{SO}_{4} 64 \%$ pada suhu 60 ${ }^{\circ} \mathrm{C}$ selama 45 menit (Aditama and Ardhyananta, 2017); hidrolisis pada suhu tetap $45^{\circ} \mathrm{C}$ dan variasi konsentrasi asam sulfat $54 \%, 56 \%, 58 \%$, dan $60 \%$, sedangkan untuk waktu hidrolisis menggunakan empat periode reaksi 40 menit, 60 menit, 80 menit, dan 100 menit (Al-Dulaimi and Wanrosli, 2017); hidrolisis menggunakan asam sulfat $50 \%$ pada suhu $40{ }^{\circ} \mathrm{C}$ selama 10 menit (Wulandari et al., 2016b); hidrolisis menggunakan asam sulfat 64 \%berat pada $45^{\circ} \mathrm{C}$ selama 60 menit (Musa et al., 2017); dan hidrolisis dengan asam sulfat $32 \%$ berat selama 24 jam (Huntley et al., 2014).

Sebagian besar proses hidrolisis asam dilakukan pada suhu pemanasan $40-60{ }^{\circ} \mathrm{C}$ dan konsentrasi asam yang cukup tinggi yaitu 50-65\%, namun Yuanita et al., 2017 telah melakukan penelitian pembuatan $M F C$ dari serat Arenga Pinnata "ijuk" menggunakan hidrolisis asam sulfat $20 \%$ tanpa pemanasan. Hidrolisis menggunakan asam sulfat $20 \%$ dan tanpa pemanasan diharapkan sudah cukup untuk menghilangkan bagian amorph dari $M F C$ dengan tetap menjaga bagian kristalinnya karena telah didahului dengan proses alkalinisasi dan oksidasi, dimana lignin dan hemiselulosa telah hilang melalui alkalinisasi serta telah terbentuk mikrofibril melalui oksidasi. Kedua proses tersebut meningkatkan luas area kontak antara mikrofibril dan asam sulfat, sehingga tidak diperlukan pemanasan dan konsentrasi asam sulfat yang tinggi. Oleh karena itu pada penelitian ini dilakukan pembuatan $M F C$ dari TKKS melalui proses hidrolisis menggunakan 
asam sulfat $20 \%$ tanpa pemanasan (suhu ruang) dan dengan variasi waktu reaksi (1 jam, 2 jam, dan 3 jam). Tujuan dari penelitian ini adalah untuk mengetahui pengaruh variasi waktu reaksi pada proses hidrolisis $\mathrm{H}_{2} \mathrm{SO}_{4}$ tanpa menggunakan pemanasan.

\section{Metode}

Bahan yang digunakan pada penelitian ini antara lain TKKS diperoleh dari suplier serat di Tangerang, Indonesia, $\mathrm{NaOH}$ teknis $98 \%$ diperoleh dari PT Asahimas Chemical, $\mathrm{H}_{2} \mathrm{O}_{2}$ teknis kemurnian 50\% diperoleh dari Taekwang, dan $\mathrm{H}_{2} \mathrm{SO}_{4}$ pro analisis diperoleh dari Mallinckrodt Baker.

\subsection{Preparasi $M F C$}

Preparasi $M F C$ dari serat TKKS terdiri dari dua proses, yaitu alkalinisasi dan oksidasi hidrogen peroksida. TKKS pertama kali dicacah dan dipotong menggunakan mesin crusher dan diayak untuk mendapatkan ukuran yang seragam (60 mesh). Serat TKKS sebanyak 5 gram direndam di dalam $\mathrm{NaOH} 4 \%$ sebanyak $100 \mathrm{~mL}$ dan diaduk di atas hotplate stirrer pada suhu $90{ }^{\circ} \mathrm{C}$ selama 2 jam. Serat kemudian dipisahkan dan disaring dari larutan $\mathrm{NaOH}$ menggunakan kertas saring. Setelah itu serat dicuci menggunakan air sampai $\mathrm{pH}$ serat menjadi netral. Sebanyak 5 gram serat TKKS hasil alkalinisasi kemudian direndam di dalam $\mathrm{H}_{2} \mathrm{O}_{2} \quad 20 \%$ sebanyak 100 $\mathrm{mL}$ dan diaduk di atas hotplate stirrer selama 2 jam. Setelah itu serat dipisahkan dari larutan $\mathrm{H}_{2} \mathrm{O}_{2}$ menggunakan kertas saring dan dicuci menggunakan air sampai pH netral (Mustafa et al., 2015).

\subsection{Hidrolisis asam}

Sebanyak 5 gram serat direndam di dalam $\mathrm{H}_{2} \mathrm{SO}_{4}$ sebanyak $100 \mathrm{~mL}$ dan diaduk di atas hotplate stirrer dengan berbagai variasi waktu reaksi (1 jam, 2 jam, dan
3 jam). Konsentrasi $\mathrm{H}_{2} \mathrm{SO}_{4}$ yang digunakan 20\% (Yuanita et al., 2017). Hidrolisis dihentikan dengan menambahkan air dingin sebanyak $500 \mathrm{~mL}$. Serat kemudian dipisahkan dari larutan $\mathrm{H}_{2} \mathrm{SO}_{4}$ menggunakan kertas saring dan dinetralkan dengan cara dicuci menggunakan air sampai $\mathrm{pH}$ netral. Setelah itu, serat dikeringkan pada suhu ruang selama $2 \times 24$ jam.

\subsection{Karakterisasi}

Gugus fungsi $M F C$ dianalisis menggunakan Fourier Transform Infrared (FTIR) seri Nicolet iS5 FTIR spectrometer. Semua spektrum menggunakan panjang gelombang $400 \mathrm{~cm}^{-1}$ sampai dengan $4000 \mathrm{~cm}^{-1}$. Kristalinitas $M F C$ dikarakterisasi menggunakan $X$-ray Diffraction (XRD) D8 Advance Bruker Germany. Stabilitas termal $M F C$ dianalisis menggunakan Thermal Gravimetric Analysis (TGA), The LINSEIS STA Platinum Series (simultaneous thermal analysis).

\section{Hasil dan pembahasan \\ 3.1. Gugus fungsi}

Perlakuan terhadap $M F C$ melalui proses hidrolisis asam dengan berbagai variasi waktu reaksi menyebabkan perubahan gugus fungsi pada serat. Gambar 1 menyajikan gugus fungsi dari $M F C$ sebelum dan setelah proses hidrolisis asam pada berbagai variasi waktu reaksi.

Pada $M F C$ sebelum perlakuan hidrolisis asam, masih terdapat lignin dan hemiselulosa, hal ini terlihat dari puncak lignin dan hemiselulosa yang masih terlihat pada Gambar 1, puncak antara $1300 \mathrm{~cm}^{-1}-1000 \mathrm{~cm}^{-1}$ menunjukkan $\mathrm{C}-\mathrm{O}$ stretch yang merupakan bagian dari hemiselulosa, pektin, dan lignin. Peak diantara $1500 \mathrm{~cm}^{-}$ ${ }^{1}-1400 \mathrm{~cm}^{-1}$ adalah $\mathrm{C}-\mathrm{C}$ stretch bagian cincin lignin (Yuanita et al., 2017), sedangkan puncak pada $1635 \mathrm{~cm}^{-1}$ merupakan - $\mathrm{OH}$ bending menunjukkan penyerapan air oleh selulosa. Puncak ini terjadi karena adanya sejumlah kecil hemiselulosa (Nasution et al., 2017).

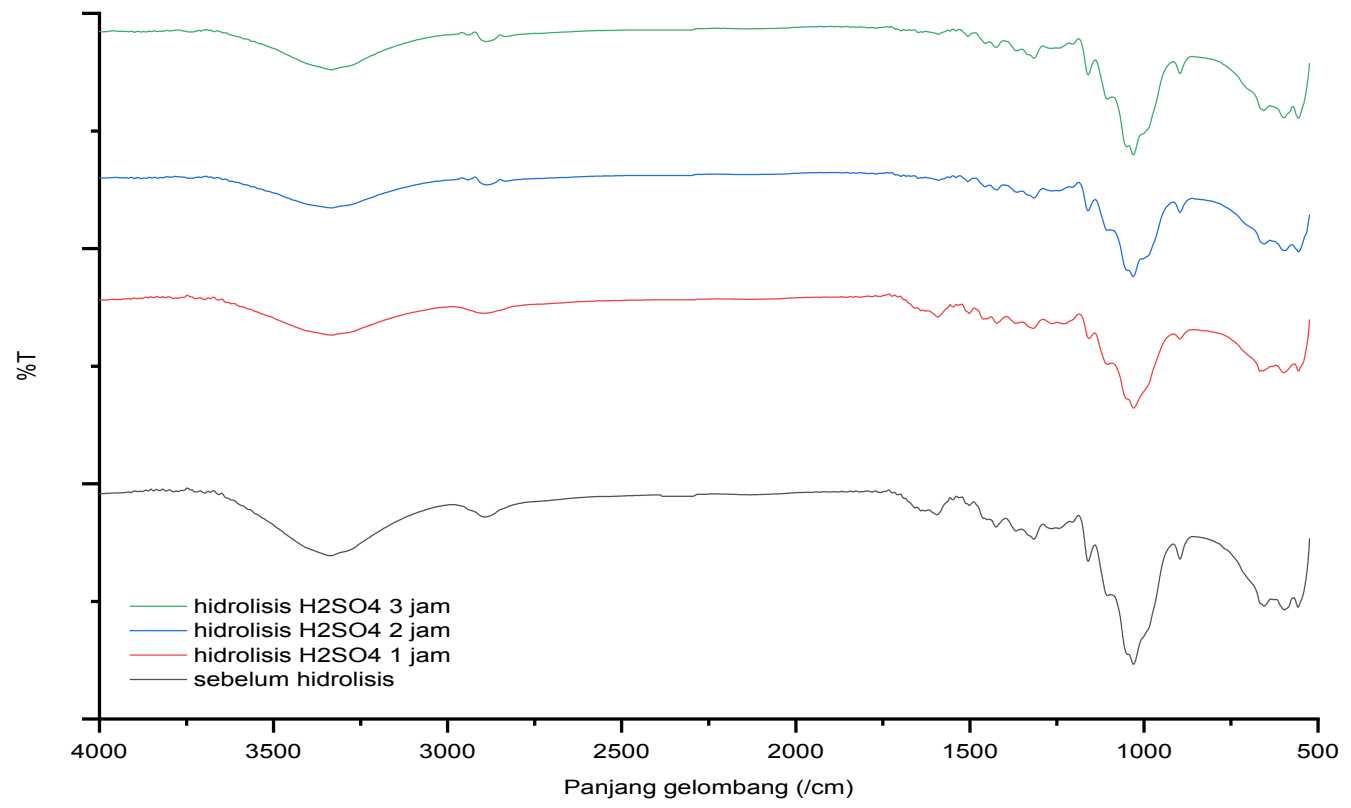

Gambar 1. Grafik spektrum $M F C$ hasil proses hidrolisis asam. 
Berdasarkan Gambar 1, setelah dilakukan hidrolisis menggunakan asam $\mathrm{H}_{2} \mathrm{SO}_{4} 20 \%$ dengan berbagai variasi waktu reaksi dari 1 jam, 2 jam, dan 3 jam terlihat penurunan konsentrasi lignin dan hemiselulosa. Hal ini ditunjukkan dari penurunan intensitas puncak C-O stretch $\left(1300 \mathrm{~cm}^{-1}-1000 \mathrm{~cm}^{-1}\right), \mathrm{C}-\mathrm{C}$ stretch $\left(1500 \mathrm{~cm}^{-1}-\right.$ $\left.1400 \mathrm{~cm}^{-1}\right)$, dan -OH bending $\left(1635 \mathrm{~cm}^{-1}\right)$ dibandingkan dengan $M F C$ sebelum hidrolisis $\mathrm{H}_{2} \mathrm{SO}_{4}$. Sebagian besar serat alam adalah polimer yang memiliki bagian amorph dan kristalin, lignin dan hemiselulosa merupakan bagian amorph. Oleh karena itu hidrolisis asam dilakukan untuk menurunkan bagian amorph (Ismojo et al., 2017).

Daerah serapan antara $3000 \mathrm{~cm}^{-1}$ dan $3355 \mathrm{~cm}^{-1}$ menunjukkan ikatan hidrogen $(\mathrm{O}-\mathrm{H})$ (Khalil et al., 2011; Yuanita et al., 2015). Berdasarkan grafik, menunjukkan penurunan konsentrasi $-\mathrm{OH}$, dibuktikan dari penurunan intensitas puncak antara $3000 \mathrm{~cm}^{-1}$ dan $3355 \mathrm{~cm}^{-1}$. Hal ini sesuai dengan penelitian yang dilakukan oleh
(Nasution et al., 2017), dimana pada proses hidrolisis asam terjadi penurunan konsentrasi - $\mathrm{OH}$. Proses hidrolisis menggunakan asam sulfat $20 \%$ dengan variasi waktu 1 jam, 2 jam, dan 3 jam belum optimal, karena gugus $-\mathrm{OH}$ belum hilang sepenuhnya, hanya terjadi penurunan. Dengan masih adanya gugus $-\mathrm{OH}$ ini, dimungkinkan dapat menyerap uap air dari lingkungan lagi sehingga dapat mengganggu kompatibilitas $M F C$ dengan matrik jika diaplikasikan sebagai nucleating agen (Kabir et al., 2012).

\subsection{Stabilitas termal}

Stabilitas termal $M F C$ sebelum proses hidrolisis asam dan setelah proses hidrolisis asam dianalisis menggunakan TGA. Hasil analisis ditunjukkan pada Gambar 2.
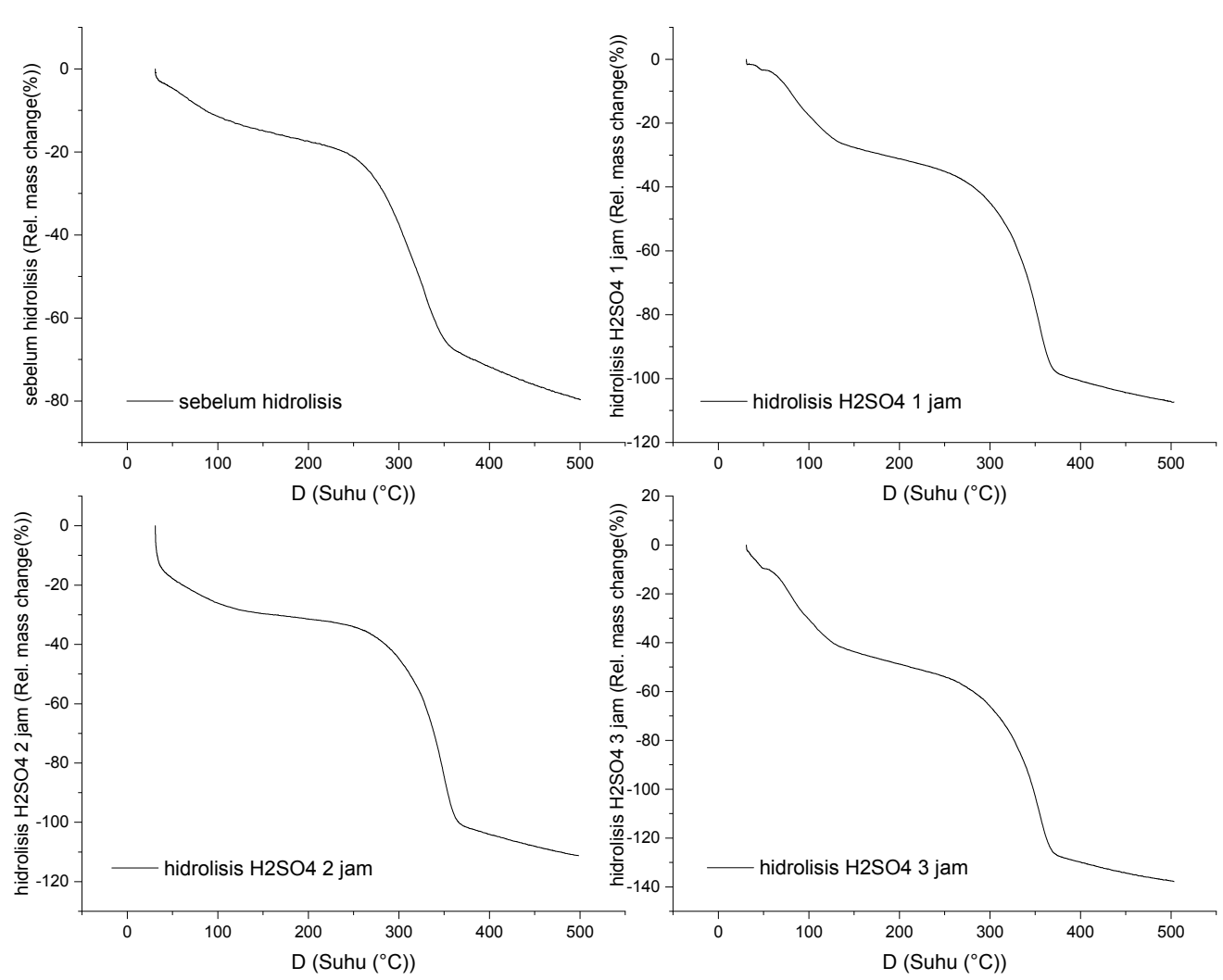

Gambar 2. Grafik analisis $T G A$ pada $M F C$ hasil proses hidrolisis asam.

Berdasarkan Gambar 2 menunjukkan bahwa uap air dan senyawa dengan berat molekul rendah hilang pada suhu sekitar $100{ }^{\circ} \mathrm{C}$. Degradasi terjadi pada suhu $30{ }^{\circ} \mathrm{C}$ sampai dengan $130{ }^{\circ} \mathrm{C}$ yang disebabkan oleh penguapan uap air dan ikatan hidrogen air yang diserap secara kimia antar molekul (Musa et al., 2017). Hal ini sesuai dengan hasil dari analisis FTIR dimana masih terdapat gugus $-\mathrm{OH}$ setelah hidrolisis dengan asam sulfat dilakukan. Pada $M F C$ sebelum hidrolisis asam sulfat, pada suhu 260 ${ }^{\circ} \mathrm{C}$ sampai dengan $360{ }^{\circ} \mathrm{C}$ merupakan dekomposisi termal dari hemiselulosa dan lignin, sedangkan pada suhu $360{ }^{\circ} \mathrm{C}$ sampai dengan $500{ }^{\circ} \mathrm{C}$ merupakan dekomposisi termal dari selulosa dan lignin (Maheswari et al., 2012). Pada $M F C$ setelah proses hidrolisis dengan asam $\mathrm{H}_{2} \mathrm{SO}_{4}$ dengan waktu reaksi 1 jam, 2 jam, dan
3 jam berturut-turut terjadi degradasi pada suhu $260{ }^{\circ} \mathrm{C}$ sampai dengan $365{ }^{\circ} \mathrm{C}, 270{ }^{\circ} \mathrm{C}$ sampai dengan $366^{\circ} \mathrm{C}$, $273{ }^{\circ} \mathrm{C}$ dan $370{ }^{\circ} \mathrm{C}$ merupakan dekomposisi termal dari hemiselulosa, lignin, dan selulosa. Dari hasil tersebut menunjukkan bahwa stabilitas termal proses hidrolisis menggunakan asam $\mathrm{H}_{2} \mathrm{SO}_{4}$ dengan waktu reaksi 3 jam lebih tinggi dibandingkan dengan waktu reaksi lainnya.

\subsection{Kristalinitas}

Kristalinitas $M F C$ dianalisis menggunakan XRD. Pola $X R D$ dari $M F C$ sebelum dan setelah proses hidrolisis menggunakan asam $\mathrm{H}_{2} \mathrm{SO}_{4}$ pada berbagai waktu reaksi ditunjukkan pada Gambar 3. 


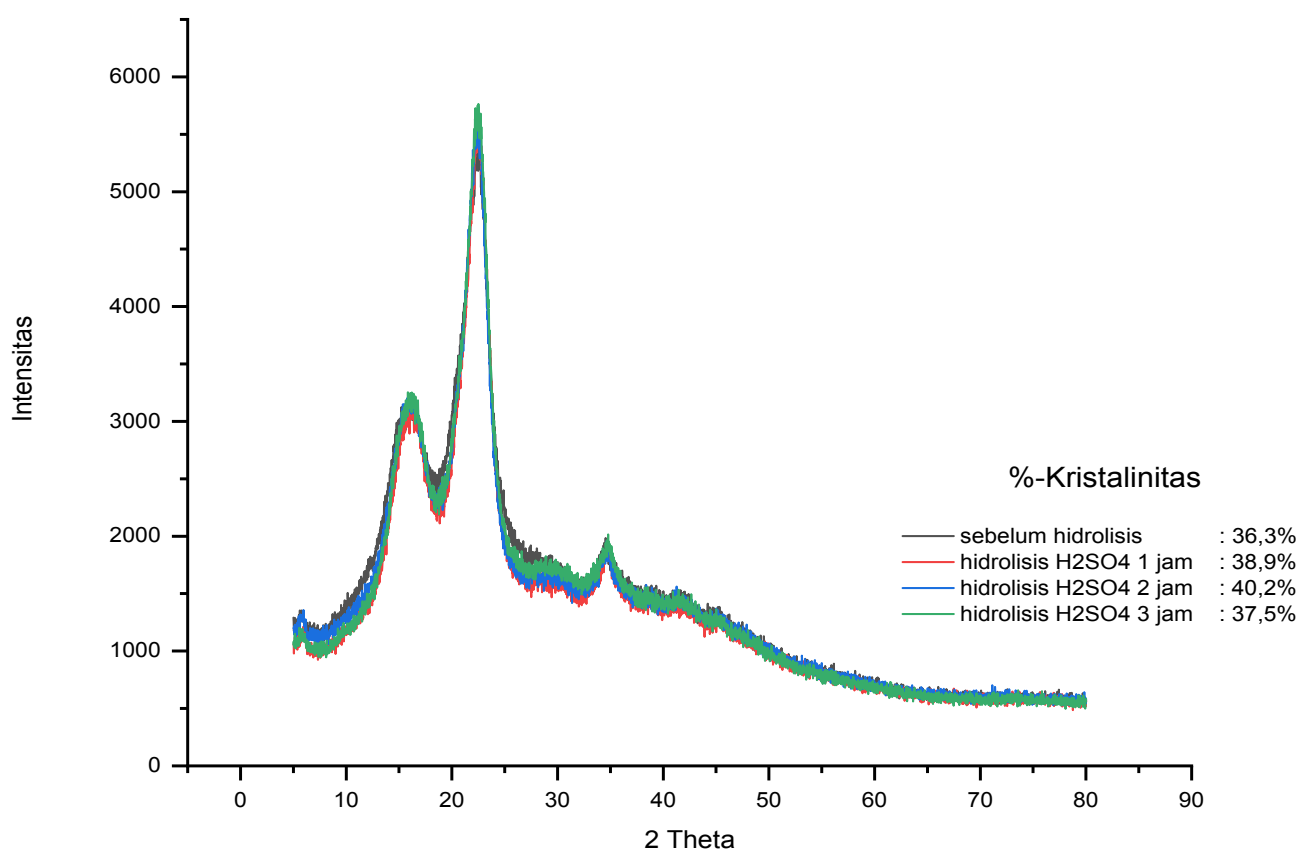

Gambar 3. Grafik analisis $X R D$ pada $M F C$ hasil proses hidrolisis asam

Gambar 3 menunjukkan pola $X R D$ dari $M F C$ sebelum dan setelah proses hidrolisis asam. Pada Gambar 3 terlihat 3 puncak yaitu disekitar $2 \theta=18^{\circ}$ dimana menunjukkan daerah amorph, $2 \theta=22^{\circ}$ menunjukkan daerah kristalin, dan $2 \theta=35^{\circ}$ menunjukkan daerah kristalin. Puncak kristalin pada $2 \theta=35^{\circ}$ menunjukkan perlakuan terhadap $M F C$ memberikan hasil yang bagus dimana terjadi peningkatan kristalinitas selulosa. Puncak ini semakin tajam, yang menunjukkan tingkat kristalinitas (French and Cintrón, 2013; Yuanita et al., 2017). Persen kritalinitas untuk $M F C$ sebelum hidrolisis asam $\mathrm{H}_{2} \mathrm{SO}_{4}, M F C$ setelah proses hidrolisis asam $\mathrm{H}_{2} \mathrm{SO}_{4}$ selama $1 \mathrm{jam}, M F C$ setelah proses hidrolisis asam $\mathrm{H}_{2} \mathrm{SO}_{4}$ selama 2 jam, dan $M F C$ setelah proses hidrolisis asam $\mathrm{H}_{2} \mathrm{SO}_{4}$ selama 3 jam yaitu $36,3 \%$, 38,9\%, $40,2 \%$, dan $37,5 \%$. Semakin lama waktu reaksi pada saat proses hidrolisis $\mathrm{H}_{2} \mathrm{SO}_{4}$ menunjukkan kecenderungan persen kristalinitas meningkat. Namun, persen kristalinitas mengalami penurunan pada saat waktu reaksi hidrolisis $\mathrm{H}_{2} \mathrm{SO}_{4}$ selama 3 jam. Hal ini karena daerah amorph dihilangkan melalui proses hidrolisis asam, namun dengan hidrolisis yang berkepanjangan, ion hidrogen tidak hanya menghilangkan bagian amorph, tetapi juga menembus daerah kristal selulosa untuk meningkatkan pembelahan hidrolitik lebih lanjut dari ikatan glikosidik sehingga menghasilkan persen kristalinitas yang berkurang (Al-Dulaimi and Wanrosli, 2017).

\section{Kesimpulan}

Pada penelitian ini dilakukan hidrolisis menggunakan asam $\mathrm{H}_{2} \mathrm{SO}_{4} 20 \%$ terhadap MFC dengan variasi waktu reaksi. Dari hasil analisis FTIR, TGA, dan XRD menunjukkan bahwa terjadi penurunan lignin, hemiselulosa, dan ikatan $-\mathrm{OH}$, stabilitas termal proses hidrolisis pada waktu reaksi 3 jam lebih tinggi dibandingkan dengan waktu reaksi lainnya, serta kecenderungan peningkatan persen kristalinitas.
Berdasarkan dari hasil analisis tersebut, $M F C$ dari serat TKKS yang diproses hidrolisis menggunakan asam $\mathrm{H}_{2} \mathrm{SO}_{4} 20 \%$ pada suhu kamar berpotensi digunakan sebagai nucleating agent.

\section{Daftar pustaka}

Aditama, A.G., Ardhyananta, H., 2017. Isolasi Selulosa dari Serat Tandan Kosong Kelapa Sawit untuk Nano Filler Komposit Absorpsi Suara: Analisis FTIR. J. Tek. ITS 6, 228-231. https://doi.org/10.12962/ j23373539.v6i2.24098

Al-Dulaimi, A.A., Wanrosli, W.D., 2017. Isolation and Characterization of Nanocrystalline Cellulose from Totally Chlorine Free Oil Palm Empty Fruit Bunch Pulp. J. Polym. Environ. 25, 192-202. https://doi.org/ 10.1007/s10924-016-0798-z

Ching, Y.C., Ng, T.S., 2014. Effect of preparation conditions on cellulose from oil palm empty fruit bunch fiber. BioResources 9, 6373-6385. https://doi.org/10.15376/biores.9.4.6373-6385

Dewanti, D.P., 2018. Potensi Selulosa dari Limbah Tandan Kosong Kelapa Sawit untuk Bahan Baku Bioplastik Ramah Lingkungan. J. Teknol. Lingkung. $19,81-88$.

French, A.D., Cintrón, M.S., 2013. Cellulose polymorphy, crystallite size, and the Segal Crystallinity Index. Cellulose 20, 583-588. https://doi.org/10.1007/s10570-012-9833-y

Gentile, G., Cocca, M., Avolio, R., Errico, M.E., Avella, M., 2018. Effect of microfibrillated cellulose on microstructure and properties of poly(vinyl alcohol) foams. Polymers (Basel). 10. https://doi.org/10.3390/ polym 10080813

Hellström, P., Heijnesson-Hultén, A., Paulsson, M., $\mathrm{Ha}^{\circ}$ kansson, H., Germga ${ }^{\circ}$ d, U., 2014. Fenton pretreated microfibrillated cellulose evaluated as a strength enhancer in the middle ply of paperboard. Nord. Pulp Pap. Res. J. 29, 732-740. 
Huntley, C.J., Crews, K.D., Curry, M.L., 2014. Chemical functionalization and characterization of cellulose extracted from wheat straw using acid hydrolysis methodologies. Int. J. Polym. Sci. 2015, 1-9. https://doi.org/10.1155/2015/293981

Ismojo, Novovic, A., Lazwardi, D.R., Zulfia, A., Chalid, M., 2019. Microfibrillated cellulose (MFC) isolation based on stalk sweet sorghum through alkalinizationbleaching treatment: Effect of soaking temperature. IOP Conf. Ser. Mater. Sci. Eng. 509. https://doi.org/10.1088/1757-899X/509/1/012079

Ismojo, Simanulang, P.H., Zulfia, A., Chalid, M., 2017. Preparation of micro-fibrillated cellulose from sorghum fibre through alkalization and acetylation treatments. IOP Conf. Ser. Mater. Sci. Eng. 223. https://doi.org/10.1088/1757-899X/223/1/012057

Kabir, M.M., Wang, H., Lau, K.T., Cardona, F., 2012. Chemical treatments on plant-based natural fibre reinforced polymer composites: An overview. Compos. Part B Eng. 43, 2883-2892. https://doi.org/10.1016/j.compositesb.2012.04.053

Khalil, H.P.S.A., Marliana, M.M., Alshammari, T., 2011. Material properties of epoxy-reinforced biocomposites with lignin from empty fruit bunch as curing agent. BioResources 6, 5206-5223. https://doi.org/10.15376/biores.6.4.5206-5223

Lepetit, A., Drolet, R., Tolnai, B., Zerrouki, R., Montplaisir, D., 2017. Effect of acetylation on the properties of microfibrillated cellulose-LDPE composites. J. Appl. Polym. Sci. 134, 1-8. https://doi.org/10.1002/app.44933

Lismeri, L., Darni, Y., 2017. Isolasi Mikrofibril Selulosa Dengan Pretreatment Alkali Dari Limbah Batang Pisang ( Microfibril Cellulose Isolation With Alkaline Pretreatment From Banana Stem Waste ), in: Prosiding Dalam Rangka Seminar Nasional Riset Industri Ke 3. pp. 40-45.

Maheswari, C.U., Reddy, K.O., Muzenda, E., Guduri, B.R., Rajulu, A. V., 2012. Extraction and characterization of cellulose microfibrils from agricultural residue - Cocos nucifera L. Biomass and Bioenergy 46, 555-563. https://doi.org/10.1016/ j.biombioe.2012.06.039

Musa, A., Ahmad, M.B., Hussein, M.Z., Izham, S.M., 2017. Acid Hydrolysis-Mediated preparation of Nanocrystalline Cellulose from Rice Straw. Int. J. Nanomater. Nanotechnol. Nanomedicine 3, 051-056. https://doi.org/10.17352/2455-3492.000021

Mustafa, J.H., Yuanita, E., Pratama, J.N., Chalid, M., 2015. Pembuatan dan karakterisasi selulosa mikrofibril dari serat ijuk dengan perlakuan kimia alkali dan oksidasi peroksida. pp. 4-5.

Nasution, H., Yurnaliza, Y., Veronicha, V., Irmadani, I., Sitompul, S., 2017. Preparation and Characterization of Cellulose Microcrystalline (MCC) from Fiber of Empty Fruit Bunch Palm Oil, in: IOP Conf. Series : Materials Science and Engineering 180. https://doi.org/10.1088/1742-6596/755/1/011001

Pradana, M.A., Ardhyananta, H., Farid, M., 2017. Pemisahan Selulosa dari Lignin Serat Tandan Kosong Kelapa Sawit dengan Proses Alkalisasi untuk Penguat Bahan Komposit Penyerap Suara. J. Tek. ITS 6, 413-416. https://doi.org/10.12962/j23373539. v6i2.24559

Saputro, A., Verawati, I., Ramahdita, G., Chalid, M., 2017. Preparation of micro-fibrillated cellulose based on sugar palm ijuk (Arenga pinnata) fibres through partial acid hydrolysis. IOP Conf. Ser. Mater. Sci. Eng. 223. https://doi.org/10.1088/1757-899X/223/ $1 / 012042$

Simanke, A.G., De Azeredo, A.P., De Lemos, C., Mauler, R.S., 2016. Influence of nucleating agent on the crystallization kinetics and morphology of polypropylene. Polimeros 26, 152-160. https://doi.org/10.1590/0104-1428.2053

Thanomchat, S., Srikulkit, K., Suksut, B., Karl Schlarb, A., 2014. Morphology and Crystallization of Polypropylene/Microfibrillated Cellulose Composites. KMUTNB Int. J. Appl. Sci. Technol. 7, 23-34. https://doi.org/10.14416/j.ijast.2014.09.002

Tristantini, D., Dewanti, D.P., Sandra, C., Tristantini, D., Purwitasari, D., Sandra, C., 2017. Isolation and Characterization of $\alpha$-Cellulose from Blank Bunches of Palm Oil and Dry Jackfruit Leaves with Alkaline Process $\mathrm{NaOH}$ Continued with Bleaching Process H2O2, in: Proceedings of the 3rd International Symposium on Applied Chemistry 2017. pp. 1-6.

Wulandari, W.T., Rochliadi, A., Arcana, I.M., 2016 a. Nanocellulose prepared by acid hydrolysis of isolated cellulose from sugarcane bagasse. IOP Conf. Ser. Mater. Sci. Eng. 107. https://doi.org/10.1088/1757899X/107/1/012045

Wulandari, W.T., Rochliadi, A., Arcana, I.M., $2016 \mathrm{~b}$. Nanocellulose prepared by acid hydrolysis of isolated cellulose from sugarcane bagasse. IOP Conf. Ser. Mater. Sci. Eng. 107. https://doi.org/10.1088/1757899X/107/1/012045

Yuanita, E., Pratama, J.N., Chalid, M., 2017. Preparation of Micro Fibrillated Cellulose Based on Arenga Pinnata "Ijuk" Fibre for Nucleating Agent of Polypropylene: Characterization, Optimization, and Feasibility Study, in: Macromolecular Symposia. pp. 61-68.

Yuanita, E., Pratama, J.N., Mustafa, J.H., Chalid, M., 2015. Multistages preparation for microfibrillated cellulose based on Arenga Pinnata "ijuk" fiber. Procedia Chem. 16, 608-615. https://doi.org/10.1016/j.proche.2015.12.099

Yuwawech, K., Wootthikanokkhan, J., Tanpichai, S., 2015. Effects of two different cellulose nanofiber types on properties of poly(vinyl alcohol) composite films. J. Nanomater. 2015. https://doi.org/10.1155/ 2015/908689 